\title{
Organizational Factors for Development of Sectoral Science, Technology and Innovation System: Venezuelan Experience in Biotechnology
}

\section{"Maria de Fátima Ebole Santana, ${ }^{1}$ Marcio Sacramento de Oliveira, ${ }^{2}$ Rosalba Gómez Martínez, ${ }^{3}$ Ângela Maria G. Martino, ${ }^{4}$ Nei Pereira Jr., ${ }^{5}$ Adelaide Maria de Souza Antunes}

"Chemical School/Federal University of Rio de Janeiro (UFRJ). Polytechnic School of Health Joaquim Venancio (EPSJV)/Oswaldo Cruz Foundation (Fiocruz). 4365 Brasil Ave, Manguinhos, Rio de Janeiro, RJ, Brazil.

${ }^{1}$ Polytechnic School of Health Joaquim Venancio (EPSJV)/ Oswaldo Cruz Foundation (Fiocruz). 4365 Brasil Ave, Manguinhos, Rio de Janeiro, RJ, Brazil

${ }^{2}$ Centro de Investigaciones en Ecologia y Zonas Aridas (CIEZA)/ National Experimental University of Francisco de Miranda (UNEFM). Mapararí St., Santa Ana de Coro, Falcón, Venezuela

${ }^{3}$ Centro de Investigaciones en Ecologia y Zonas Aridas (CIEZA)/ National Experimental University of Francisco de Miranda (UNEFM). Mapararí St., Santa Ana de Coro, Falcón, Venezuela

${ }^{4}$ Chemical School/ Federal University of Rio de Janeiro (UFRJ). 149 Athos da Silveira Ramos Ave, Ilha do Fundão, Rio de Janeiro, RJ, Brasil.

${ }^{5}$ Instituto Nacional de Propriedade Industrial (INPI). 7 Praça Mauá, Downtown, Rio de Janeiro, RJ, Brasil.

\begin{abstract}
Biotechnology is a millenary science, however, was in the last 60 years which reached its "peak/top" with the advances in the techniques for manipulating living beings. About your multidisciplinary nature, in the countries where it was considered a strategic element for technological innovation, many systems of organization have been developed for their own development. In order to analyze preliminary organizational factors of developing a National Innovation System for Biotechnology in Venezuela, we conducted this study using interviews and electronic questionnaires with different actors in the system of $R \& D$ : universities researchers, funding agencies, representatives of government and companies. This paper suggests some strength such as Venezuelan tradition in Biotechnology and high level of human capital qualification. Biotechnology in Venezuela was mainly developed in public research institutions such as universities and government centers, with two priority areas: agriculture and life science. However, there is a long way forward before Biotechnology is incorporated in the desired economic and social development, such as: the development of mechanisms for continued government funding and venture capital to create start-ups enterprises, strengthening strategies links between universities and companies and networking, and the development of a specific legislation for Biotechnology.
\end{abstract}

Keywords: Biotechnology, Sectorial Innovation System, Governmental Policies, Human Resources, Venezuela

Abbreviations: CvLac: National Research Council, PNCTI: National Science, Technology and Innovation Plan RICYT: Network of Ibero-American and Inter-American Science and Technology Indicators, FVPI: Venezuelan Foundation for the Promotion of Research, ONCTI: National Observatory of S,T\&I, RedBio: Network of Technical Cooperation in Agricultural Biotechnology for Latin America and the Caribbean

\section{INTRODUCTION}

The past and the present times are accompanied by important changes in the areas: technological, political, socio-economic and competitive. Especially in the technology field, the changes have marked profoundly the History of humanity resulting in social, economic, institutional and cultural transformations, which today are lived with technological advances in the cybernetics, Biotechnology and microelectronics fields. 
This technological progress has proclaimed a new paradigm based on the development of a set of intensive knowledge on scientific technologies, appointed for several author like "knowledge society". These technologies, like Biotechnology and Nanotechnology, represent a range of applications of scientific discoveries, whose core is to develop an increasing competence to manage information and knowledge, as well as their direct applications in the production process. In this contemporary setting, the intangibles such as information, knowledge (know how) and innovation become increasing value strategic variables to occupy the center of contemporary forms of capital accumulation [1]

In this "knowledge society", the role of technical and organizational innovation is considered as a strategic tool, requiring a detailed understanding of the innovative process in its dynamics, motivations and causes. The innovative process does not take place unilaterally and linearly. It is observed that the innovative process is marked by the existence of multiple mechanisms of interaction, interpolation and feedback, involving simultaneously the performance of a group of actors, organizations and governmental or private institutions that interact with each other in order to obtain, develop and share information, resources and knowledge [2].

Concerning this perception, the concept of innovation system seems to be a very promising instrument in catchment of this dynamic since it does not assume the innovative activity as an exclusive phenomenon of R\&D activities carried out within companies or research institutions but rather, as a process involving multiple and heterogeneous actors that have different competencies, motivations and organizational patterns. The Innovation Systems approach has a greater emphasis on looking for an understanding of the role of each actor individually and in relation to the other actors involved in innovation. In this sense, in a highly competitive environment, regional growth and development are largely associated with the performance of innovation systems, the intensity and the effectiveness of interactions among the actors involved in the creation and diffusion of new knowledge and technology.

According to [3]: "The National Innovation System encompasses agents from the public and private sectors that interact, thanks to which they initiate, import, modify and diffuse new technologies." The central idea from this systemic view is the valorization of interaction building between the components of the system, encompassing institutions, organizations and individuals.

However, according to [4] a National Innovation System is characterized by the Triple Helix, ie., composed of three vertices: the governmental, which defines the macroeconomic and regulatory context; the academic, who produces and disseminates knowledge and; the producer, which includes industrial and business capacity. Intense collaborative activities among universities, industries and government agencies also have been cited on National Innovation Systems, emphasizing the importance of building national or international networks in this innovation process.

Countries with rich biodiversity, competence in human resources and scientific technological capacity to work in industry such as Brazil, Colombia, Peru and Venezuela, among others, have tried to establish a Sectorial System of Innovation in Biotechnology, which allows a better optimization and application of scientific resources and economic and that can generate technological products based on a nationally developed Biotechnology, consequently, would direct to a greater competitive advantage of the national industry in the global market [5. It should be noted that Biotechnology was identified as a priority area by the Venezuelan Government since 2005 in the National Science, Technology and Innovation Plan (PNCTI).

The present study aims to analyze some aspects essential to interact with production related to the formation of a Sectorial System of Innovation: the governmental structure and the academic structure of the scientific-technological management, and the business structure, in order to present an overview of Biotechnology organizational development in Venezuela, to analyze of the country's strengths and weaknesses in the relative sector.

\section{MeTHOdOLOGY AND RECOVERY DOCUMENTS}

\subsection{Database to Analyze the Venezuelan Structure of Science, Technology and Innovation}

For the analysis of the profile with respect to the organization of Science and Technology in Venezuela, the international database of the Network of Ibero-American and Inter-American Science and Technology Indicators - RICYT was used in the period from 2000 to 2014, in order to obtain 
Organizational Factors for Development of Sectoral Science, Technology and Innovation System: Venezuelan Experience in Biotechnology

information regarding government investments in S,T\&I, without party-political interest. Besides this step, a bibliographic research was also carried out.

\subsection{Database to Analyze Biotechnology in Venezuela}

In this research, three different tools were used to collect data: electronic questionnaires, bibliographic research and interviews. Unfortunately, there are no lists of "experts" in the area and we had to start building our own list relying more heavily on the academic community. Using 60 distinct terms (Table 1) related to Biotechnology was possible to build a list of researchers through three others databases:

- CvLAC (Platafforma Lattes), of the Venezuelan Foundation for the Promotion of Research (FVPI);

- National Observatory of S,T\&I (ONCTI);

- Network of Technical Cooperation in Agricultural Biotechnology for Latin America and the Caribbean (RedBio/ProfRedBio).

The following key institutions were interviewed: Ministry of Science and Technology (MCT), IDEA: Institute of Advanced Studies Foundation, IVIC: Venezuelan Institute of Scientific Research, CENDES: Center for Development Studies/Central University of Venezuela, CIEPE: State Research Center for Experimental Agroindustrial Production, INIA: National Institute of Agricultural Research, Polar Company/Polar Technological Center, QuimBiotec/Technological Complex of Venezuelan Government.

\subsection{Strategies for Recovery Documents for Biotechnology}

For recovery of significant and coherent set of information that allow an analysis of the scientific profile in the Biotechnology area was the elaboration of a complex search expression, consisting by a large of set selected keywords. For the analysis results in an accurate overview of the subject, ideally, the "search expression" must promote the recovery of all relevant research's projects on the subject and the researchers present in the databases.

The information was obtained in three stages. First, in order to achieve the purpose of mining scientific information on Biotechnology in Venezuela over a 15 years period (2000-2014), 60 distinct descriptors were used in the profiles of the experts and the research groups in Biotechnology area sought in the databases CvLAC Venezuela and ONCTI. It is noteworthy that the choice of experts was held in order to cover the breadth of Biotechnology.

Second, we interviewed Venezuelan experts selected from the Biotechnology area who work in the areas of management and regulation (ministries), research (universities and research institutes) and innovation (private companies). With this phase, the objectives were to identify: (i) A general overview of the sector; (ii) Organizations active and their locations; (iii) Biotechnology areas; (iv) Research projects, networks and international partnerships.

During the third phase, electronic questionnaires were applied to the researchers and, finally, the information was verified in the organizations' web pages.

\subsection{Processing of Information}

The processing of scientific information retrieved was performed using the software Vantage Point ${ }^{\circledR}$ as a tool for text and data mining to expand and enrich the results. The treatment step of the information obtained aims to eliminate the possible noises as the duplicity of the data collected. This tool of information management allows you to present correlations of different variables of interest and, later, a hierarchical data was performed and basic statistical analysis was applied.

For visualization of the data, we used the software VOSviewer®. It is a recent free software for the representation and analysis of information, which appears as an alternative to the traditional techniques of multidimensional representation and network display [6].

\section{RESUlTS AND DisCuSSIONS}

\subsection{Organization of Science, Technology and Innovation (S,T\&I) in Venezuela}


The first development evidences of the Venezuelan National System of S\&T date from 1975 when was created the Ministry of State for Science, Technology and Culture and, in 1978 was created the Ministry of State for Science and Technology.

However, in the 1980s it begun structure the regionalized research with the development of most regional S\&T organizations affiliated to the National Council for Scientific and Technological Research (CONICIT), now known as FUNDACITES (Science and Technology Foundations for development), with emphasis on regional requirements. Nowadays, 20 foundations are located in all the Venezuelan states [7].

In 1999 was created The Ministry of Science and Technology (MCT), today named the Ministry of Popular Power for Science and Technology (MppCT), with the purpose of articulating and proposing the formation of a National System of Science, Technology and Innovation in Venezuela, ie, a model of management network composed on multiple exchanges between the actors involved. There are many public institutions that work with research, scientific and technological management that is under MCT coordination, such as FONACIT, CIEPE, IDEA, FVPI, INIA, IVIC and Quimbiotec, among others.

In 2001, the Organic Law of Science, Technology and Innovation (LONCTI) was promulgated and established a milestone to strengthen the social capacity to creation and absorption of knowledge, to adapt the supply of science and technology developed in the country to social demand, to stimulate the transfer of knowledge generated in research institutes to the society and its relevant application to solve problems of national interest.

In 2006, the National Observatory of Science, Technology and Innovation (ONCTI) was created from the Venezuelan Foundation for the Researchers Promotion (PVPI). The ONCTI has the purpose to evaluate the Venezuelan S,T\&I system by providing S,T\&I indicators that measure the social and economic impact of S,T\&I policies and programs.

The MppCT aims to carry out the National Plan for Science, Technology and Innovation 2005-2030, a 25-year future planning perspective, under which were defined areas which are considered strategic, and the lines of research to be supported with public financial resources at medium and long term. The management model of the National S\&T System articulates the four main actors: the Academic Sector, the Productive Sector, Government and Society, where each actor is represented by its institutions (Figure 1).

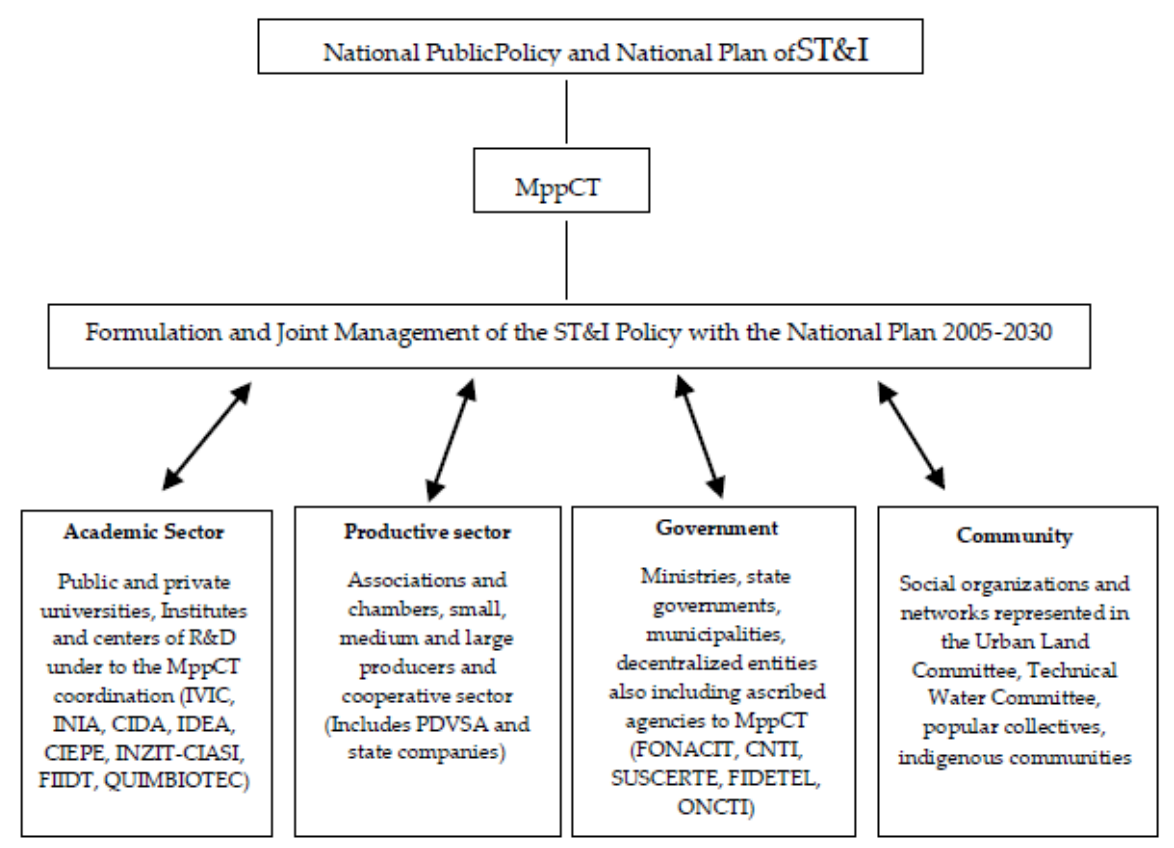

Figure1. Management model of the National Science, Technology and Innovation System. Adapted [7]

According to this plan and ONCTI data, it was possible to observe that R\&D activities were carried out primarily in universities (74.7\%) followed by public research institutions (23.1\%). It worth highlighting that the companies with R\&D activity represent less than $1 \%$ of the total [8] 
The Organic Law of Science, Technology and Innovation contemplates a mechanism that requires the participation of the productive sector in R\&D activities and technological transfer processes through investment between 5 and $20 \%$ of the financial resources of the own company. This mechanism provided a change in the profile of investment in ST\&I in the country, where the business sector starts to act more currently.

The Government for many years was the responsible for the investments in R\&D. However, considering a period of 15 years, the average percentage applied $(0.74 \%)$ is still far from that recommended by UNESCO. Figure 2 presents the government investments in R\&D activities. It worth noting that this scenario has changed since the implementation of LONCTI in 2001, where the business sector was encouraged to invest more in internal $\mathrm{R}, \mathrm{T} \& \mathrm{I}$ activities or in partnerships with public institutions.

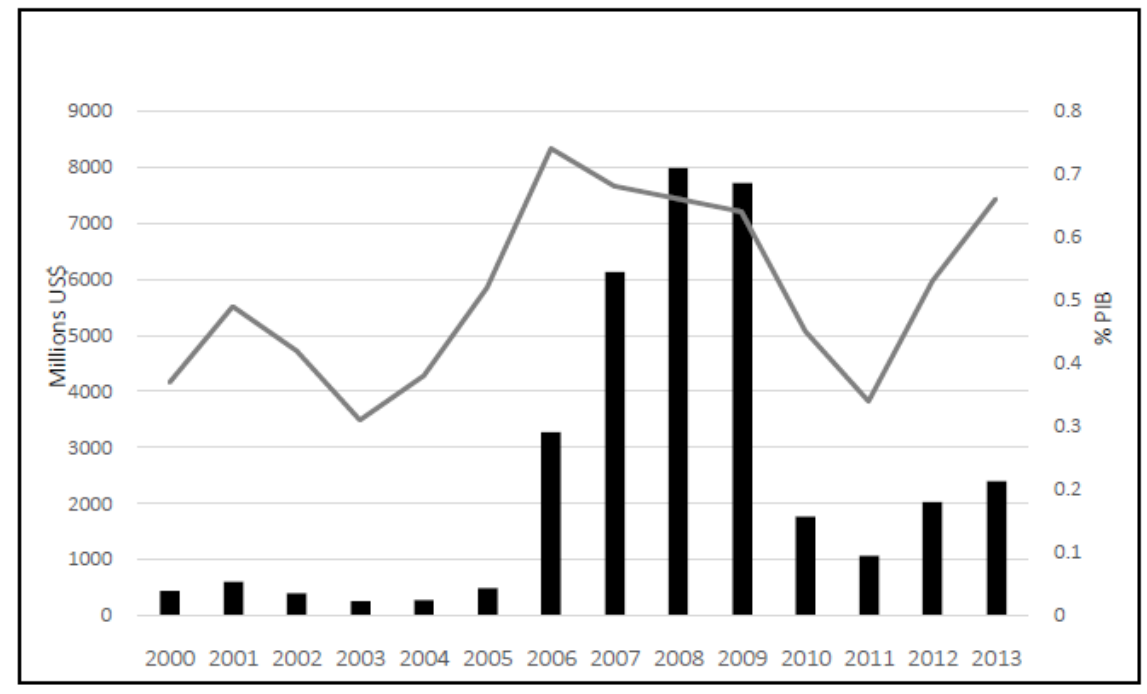

Figure2. Historical Governmental Investments in R\&D activities for period 2000 to 2013

Regarding the training of human resources into P\&D activities, it is important to point out that Venezuela does not have an articulated system and that it represents all the researchers working in the country. For this analysis of the human resources profile, a total of 11,873 researchers were identified. Figure 3 presents the historical evolution of researchers.

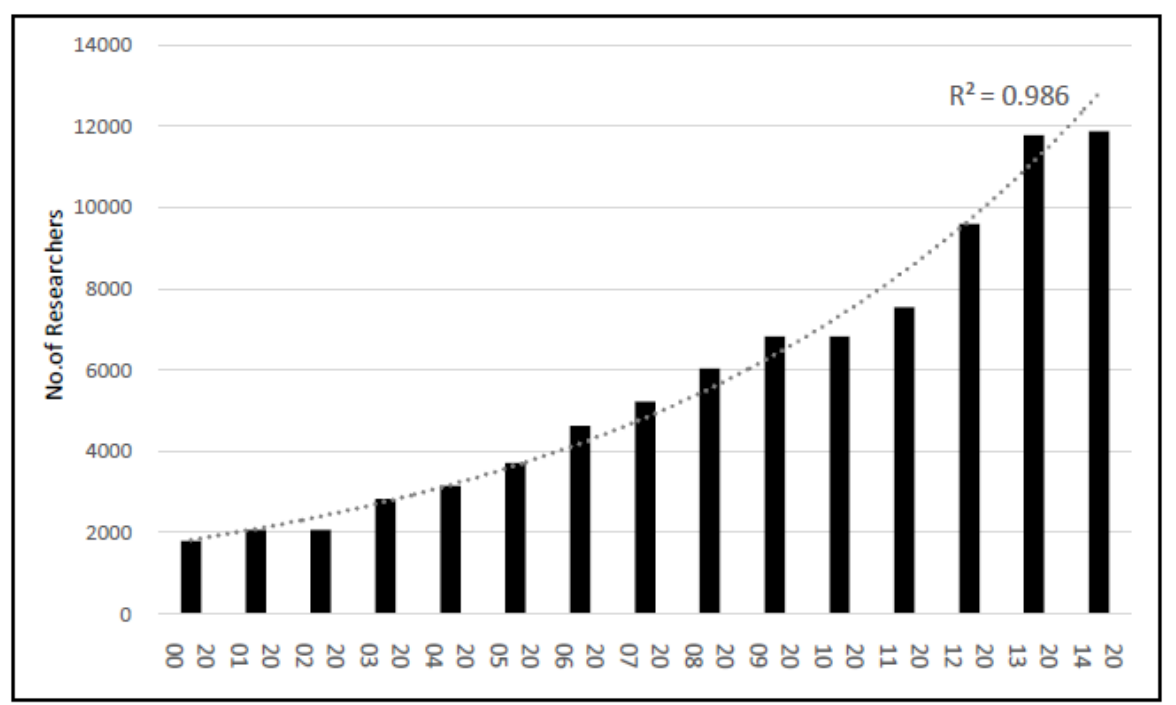

Figure3. Historical Evolution of Number of Researchers in Venezuela for the period 2000 to 2014

It is important to analyze that the number of $\mathrm{PhD}$ researchers $(31,4 \%)$ has been increasing over time due to the incentive policy training in international institutions offered by FPVI and, the governmental incentive that these professionals to stay and work in your country. This tendency to increase human resources training should increase from the complete implementation of the National Science, Technology and Innovation Plan 2005-2030, since it includes a human resources training plan. 


\subsection{Venezuelan Government Programs and Policies in Biotechnology}

The government programs to support the development on Biotechnology in Venezuela have started since the first half of the 1960s with the financing a research program to adaptation of plant tissue culture techniques for the plant breeding to be applied in agriculture.

However, since the beginning of the 1980s, the most important government action to support the development and financing on Biotechnology in Venezuela was through the formation of a committee of Ad-hoc researchers in order to dedicate to Biotechnology researches, coordinated by the National Council of Science and Technology/CONACIT. Since then, several programs and policies have been implemented for the structuring and development the area in the country. The Table 1shown the programs and policies in Biotechnology area since 2000.

Table1. Biotechnology Related Terms used to Search Articles in databases

\begin{tabular}{|l|l|l|l|}
\hline Antisense & Biomaterial & Proteins Engineering & GMO \\
\hline Recombinant Antigen & Biopolymer & Genetic Engineering & Protein \\
\hline Biodiversity & Bioprocess & MetabolicEngineering & RecombinantProtein \\
\hline Biocatalyst & Bioprospection & Molecular Engineering & Proteome \\
\hline Biofuel & Bioreactor & Gene Expression & Proteomic \\
\hline Bioeconomy & Bioremediation & Pharmacogenomics & PCR \\
\hline Bioengineering & Biosensor & Phytoremediation & RNA \\
\hline Bioethics & Biosorption & Gene & Microarray DNA \\
\hline Biofiltration & Biosurfactant & Genetic & Microarray RNA \\
\hline Bioindustry & Biosulfurization & Genome & Transcriptome \\
\hline Bioinformatics & Biotechnology & Genomic & Transgenic \\
\hline Biolixiviation & Stemcells & Microbiota & CellularTherapy \\
\hline $\begin{array}{l}\text { Computational } \\
\text { Biology }\end{array}$ & Cloning & Biology Modelling & Gene Therapy \\
\hline Biome & & & \\
\hline Biomass & Cells & Nanobiotechnology & Molecular Therapy \\
\hline
\end{tabular}

There exists in the country a governmental structure directed to the development of the area that permeates several Ministries such as: the Ministry of Science and Technology and Innovation (MCTI), the Ministry of Environment Agriculture and Lands, Food, Industry and Commerce; The Ministry of Production and Commerce; The Ministry of Health and Social Development. In addition, the Government acts through its agencies, the academic and private sectors. However, according to [9], these different entities that make up the C \& T system are not well articulated with very little institutional network formation, presenting this item as a challenge to transform management The potential of biotechnology in the country [1].

The financing of biotechnological research was carried out by federal, private and international agencies. The Organic Law of Science, Technology and Innovation (Decree No. 1290 of 26/9/2001) defines some responsible organizations on the national and regional levels as the National Center of Information Technologies/CNTI; National Observatory of Science, Technology and Innovation/ ONCTI; Foundations for the Development of Science and Technology/Fundacite and the National Foundation for Science, Technology and Innovation/FONACIT represents a leading national organization.

In the late 90th and mid-2000s FONACIT financed a significant number of projects in the area of Biotechnology through an agreement between the Inter-American Development Bank and FONACIT (BID-FONACIT), which had some objectives as training human resources, strengthening international networks, offer better infrastructures to research centers and technology transfer. This allowed direct significant financial resources for researching in this area in the country and supported the following priority areas: plant and animal breeding, food technology, immunology and bioinformatics, diagnosis and prospecting on biotechnology and detection of genetically modified organisms [9]. These programs financed some projects led by research institutes such as The Venezuelan Institute for Scientific Research/ IVIC, the Foundation Institute of Advanced Studies/ IDEA, the National Institute of Agricultural Research/INIA, among others.

From the wide vision, it was possible to realize that investments and government policies for Biotechnology were discontinued over the time and unequally distributed, which led to the existence 
of well structured centers (islands of excellence), such as IDEA and IVIC. In this perspective, according to interviews and questionnaire applied, $65 \%$ of researchers considered that government involvement in scientific research in Biotechnology was insufficient, and this discontinued financial support was the main reason, which led to the discontinuation or even failure of many research projects.

In 2007, Biotechnology had identified as a cross priority area by the National Science, Technology and Innovation Plan (PNCTI) to receive government incentives from another areas considered essential such as: Oil, gas and energy (alternative energy and biofuels); Food safety (food technology and health and animal reproduction) Public health (communicable diseases, biotechnology, immunology and bioequivalence), Habitat and development (biodiversity); Information technology (bioinformatics).

\subsection{Profile of the Scientific Sector: Biotechnology}

With regard to the scientific information retrieved on databases for the period between 2000 to 2014, this section analyzes some constituents elements for the R\&D development in the Biotechnology area, observing important aspects as performance profile of researchers (human resources); the main knowledge areas; and the centers of excellence in R\&D that make up the Organizational Structure of Biotechnology in Venezuela.

From the methodology as already mentioned, was possible identify 546 researchers registered on the databases previously mentioned belonging to macro area Biotechnology in Venezuela until 2014, ascribed in 115 different $R \& D$ organizations.

Biotechnology permeates many areas of knowledge because its intrinsic multidisciplinary characteristics. Therefore, when analyzing the frequency of expertise area of the researchers it was possible observe there is a predominance of Agricultural Science (45\%), followed by Life Science (27\%) and Medical Sciences (9\%). However, this study highlights the wide dispersion of scientific research projects by all thematic areas. Figure 4 demonstrates this percentage distribution for all the areas.

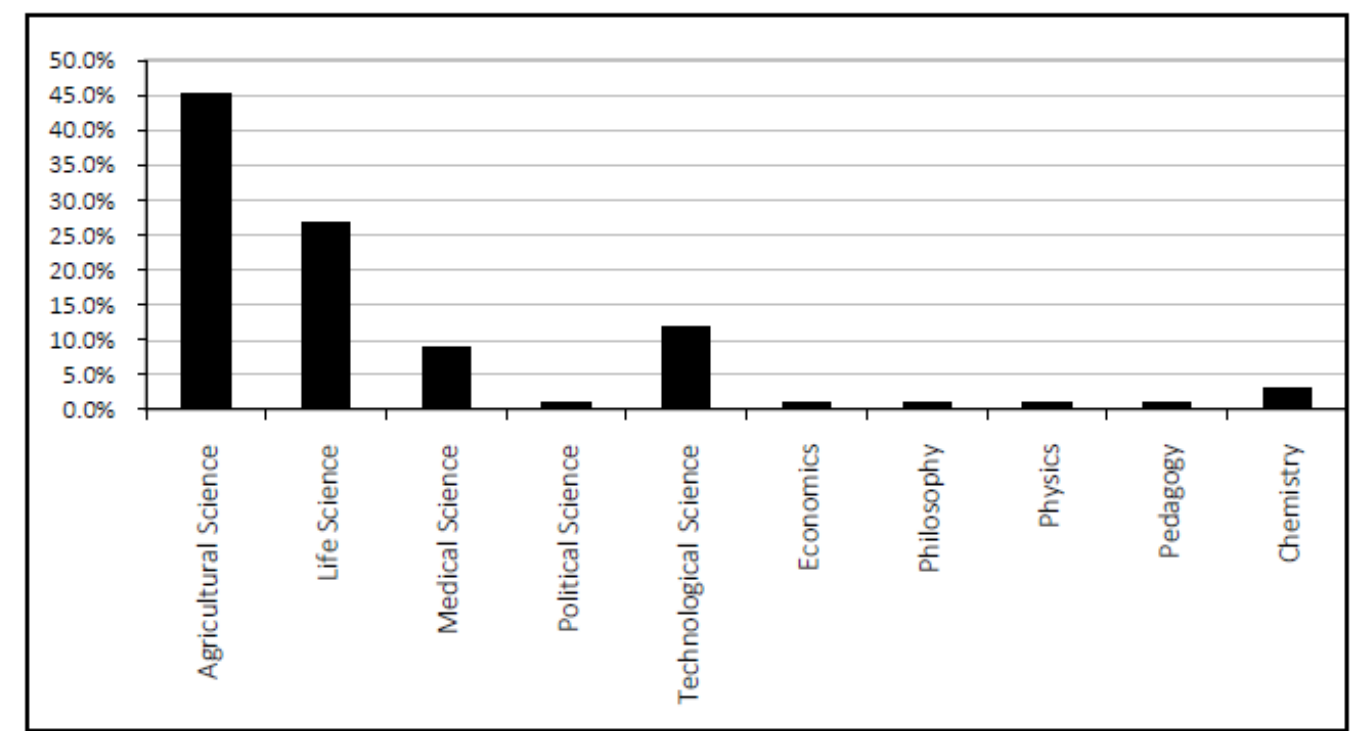

Figure4. Percentage Distribution Organization Research of Biotechnology by Areas of Knowledge for the period 2000 to 2014

It can be observe that most of the researchers' performance found is in the areas like Agriculture and Life Sciences, highlighting specific areas such as Bio agriculture, Biomedicine, Bioinformatics and Genomics. The predominance of these areas was already expected due to the characteristics of Biotechnology, but it is interesting to note that areas such as Ecology (14\%), Molecular Biology (9.5\%) and Microbiology (8\%) have a significant interest towards other traditional areas such as Food and Pharmaceutical industries. It should be emphasized that the data collected point out that scientific research on Biotechnology in Venezuela is directly related to the study of some relevant social problems of a country mainly related to tropical diseases, presenting areas as Medicine Tropical $(6.2 \%)$ and Infectious diseases (6\%) in the overview, as viewed in Figure 5. 
The research results presents qualitatively training of researchers in the area of Biotechnology, which $45 \%$ researcher have $\mathrm{PhD}$ degree and $42 \%$ master degree, where most of the time, this training took place in foreign countries because according to the [10], there are only 49 Postgraduate Programs representing this area, i.e., $2.5 \%$.

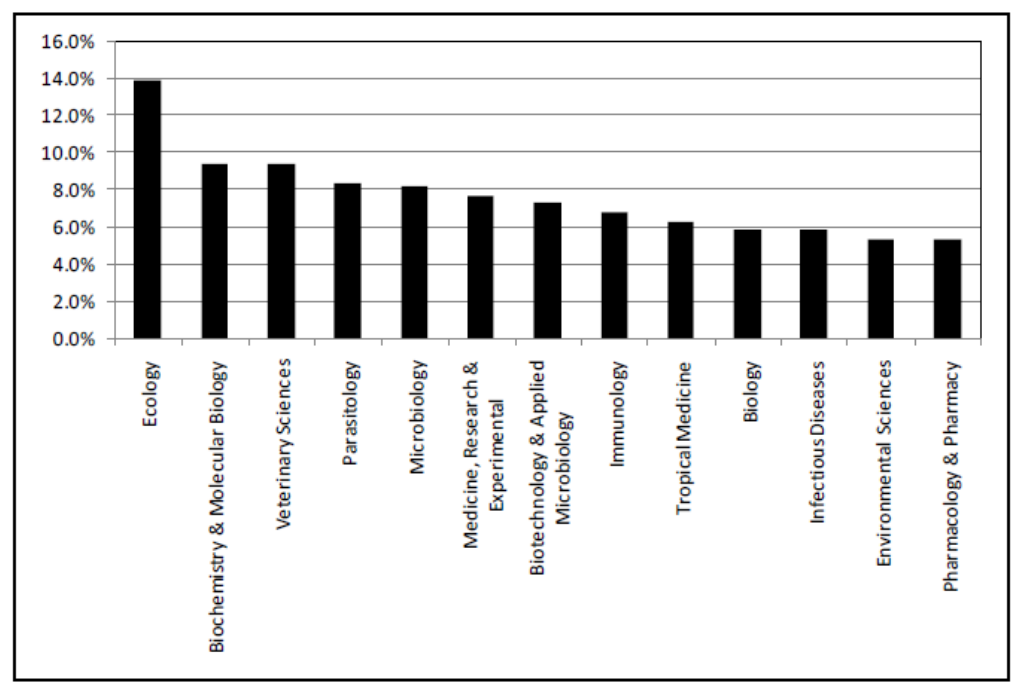

Figure5. Percentage Distribution of researchers' performance on Biotechnology by Areas of Knowledge for the period 2004 to 2014

Considering the researchers' affiliation, it was observed that there are 155 institutions, showing a high dispersion among the researchers' institutions in Venezuela. It's important to highlight the significant number of the researchers in Biotechnology are concentrated in the University of Zulia/LUZ (26\%), followed by the Central University of Venezuela/UCV (17\%) and University of the Andes/ULA (14\%) and National Institute of Agricultural Research/INIA (9\%), respectively. Figure 6 shows the distribution of Leading Venezuelan institutions with major research projects in Biotechnology. At this study, was possible observe that the majority of biotechnological researchers work in public universities and few are dedicated to private companies. This trend was already observed by [11].

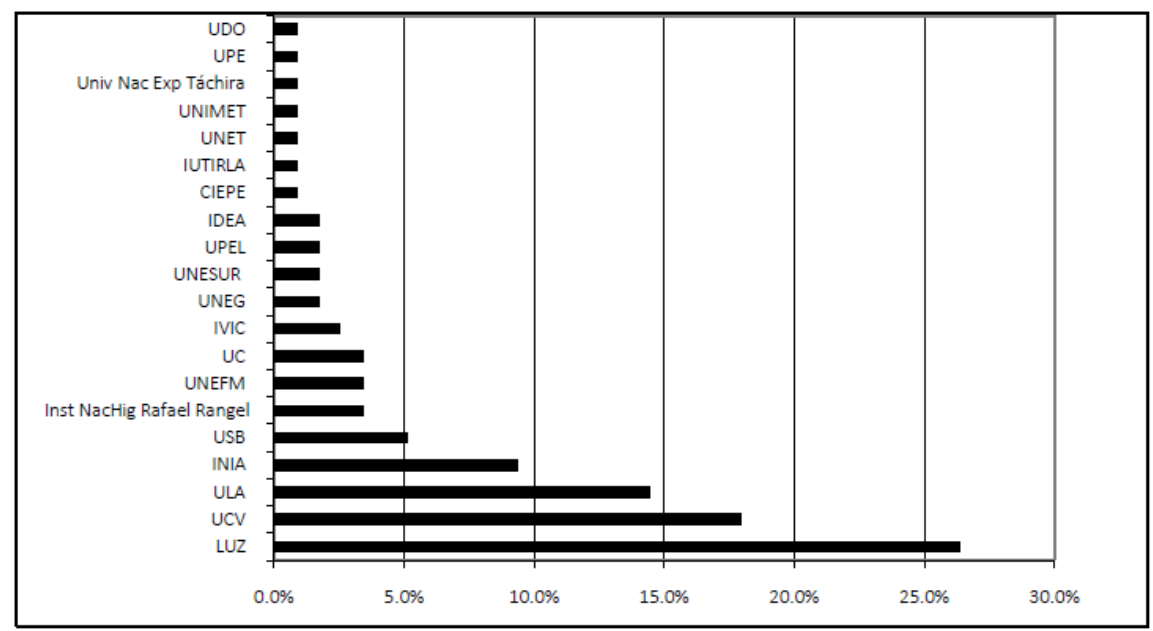

Figure6. Leading Venezuelan institutions with major research projects in Biotechnology for the period 2000 2014

The Agricultural has a greater representativeness in Biotechnology area and it is a traditional research field in Venezuela representing your strength point. Note, also, that there are a considerable number of the researchers at this specific area in Biotechnology. Therefore, this study identified 210 researchers devoted to the agricultural area (38.47\%), according to the following specialties: Plant Biotechnology (53.5\%), Animal Biotechnology, Genomic molecular modeling (10.5\%) and Bioinsecticides (1.42\%).

An interesting fact observed in relation to agricultural Biotechnology institutions is the leadership of the UCV, which concentrate $23 \%$ of the researchers devoted to this particular area, followed by the INIA (16\%) and The Venezuelan Institute for Scientific Research /IVIC (12,5\%), respectively. 
Considering a analyze of overview of the profile institutions, another prominent factor to be observed is the predominance of public governmental institutions such as universities or research centers, revealing a concentration of activities in Biotechnology by public institutions or nonprofits corporations in both academic and research levels. Government institutions represents $80 \%$ while private companies and non-profit foundations represent the $20 \%$ remaining. The highlight point observed in the researcher's interview and supported by the data is that research on Biotechnology is more related to basic research than to the development of technology and / or innovation itself directed at industrial activity.

According to the researchers interviewed and the questionnaires, the area of Biotechnology in Venezuela is very focused on academia and little on the area of industry, which stands out as a quite inexpressive sector or almost non-existent. Another important finding was the lack of collaboration between the development of research projects between universities or public institutes and the industries. According to the interviewees, more than $70 \%$ have the perception that this type of relationship between university-industry is infrequent in Venezuela for the area.

\subsection{International Partnership and Thematic Networks on Biotechnology}

The networking plays an essential role in the innovative process, especially if it concerns to Biotechnology area, which is considered to be a multi-disciplinary, highly interactive and R\&D intensive technology. Networks allow interaction, knowledge sharing and technologies and cooperation between researchers and/or institutions at the same area, thus contributing to accumulate knowledge [12].

Regarding collaboration and the strengthening of networks, the Venezuelan Association for the Advancement of Science (AsoVAC) has particular importance. It is an organization composed mainly of scientists and associate professionals, whose mission is to promote the progress of Venezuelan scientific research. AsoVAC's mission is disseminate scientific knowledge endogenous and those worldwide. There is also a program of MCTI that it aims to incorporate and articulate the different social and institutional actors of ST \& I through economic, social, academic and political networks for the intensive and extensive use of knowledge, in order to promote endogenous development [13].

In accordance with interviews and questionnaire respondents, Venezuelan research institutions and universities have a good relationship with foreign institutions. This aspect can be observed through the flow of researchers and graduate students (masters and doctorates) and postdocs who participate in projects or even spend six months in other foreign institutions in areas related to Biotechnology, since Spain, England and USA the mainly searched countries. There are some Government Programs in Venezuela to support the training of researchers in Biotechnology in other countries, but it is still necessary to improve this system, and it is currently the greatest governmental incentive to ensure good working conditions to researchers who wish to return to Venezuela and perform your Research in the country.

Venezuela retains some bilateral agreements of scientific and technological cooperation for training human resources and technological development, aimed to create international partnerships with several countries as Argentina, Brazil, Chile, China, Cuba, Iran, Russia and India [14, 15].

In addition to the bilateral agreements, there are several thematic networks that allow interaction between the different actors in the Biotechnology area in Venezuela, such as CambioTec; RedBio; REVYDET, CYTED, Alfa/Self-Rule Network, among others. According to reference [16] was identified 35 thematic networks active in Venezuela in 2003.

Many institutions that are currently researching in Biotechnology in Venezuela are members of different national and international networks, mainly Latin American. In this present study was possible observe that were 39 networks linked to the Venezuelan research groups identified through database, in 2014. The Table 2 lists the networks linked to research groups in Venezuela.

Table2. Programs and Policies on Biotechnology for the period 2000 to 2014

\begin{tabular}{|l|l|}
\hline Year & GovernmentalProgramsand Policies \\
\hline 1982 & $\begin{array}{l}\text { CONICIT: Creates the Ad-hoc Commission dedicated to Biotechnology researches and alternatives } \\
\text { for its development in Venezuela }\end{array}$ \\
\hline 1984 & The National Commission of Genetic Engineering and Biotechnology (CNIGB) was created \\
\hline 1992 & The New Technologies Program (PNT) was created by CONICIT using BID`s funding Inter- \\
\hline & American Development Bank (BID) funding \\
\hline
\end{tabular}




\begin{tabular}{|l|l|}
\hline 1994 & Actions in biosafety and bioethics area were begun promoted by CONICIT \\
\hline 1996 & The National Commission of Biotechnology was established by the Presidency \\
\hline 1999 & $\begin{array}{l}\text { Creation of the Bioethics and Biosafety Committee followed by the publication of the first edition of the } \\
\text { Bioethics Code. The MCT is also created and CONICIT allocates resources for Biotechnology through } \\
\text { the Agenda Program }\end{array}$ \\
\hline 2001 & $\begin{array}{l}\text { The Organic Law of Science, Technology and Innovation was published. The MCT and BID financed } \\
\text { important projects in the area }\end{array}$ \\
\hline 2002 & MCT: responsible for the Biotechnology politics (National Program of Biotechnology/PNB) \\
\hline 2003 & $\begin{array}{l}\text { The National Biotechnology Program is included in the National Food Security Program. The projects } \\
\text { and programs for human resources training and related areas continued receive financing }\end{array}$ \\
\hline 2004 & $\begin{array}{l}\text { The BID/FONACIT II Program is launched, followed by the National Science, Technology and } \\
\text { Innovation Plan (2004-2005) }\end{array}$ \\
\hline 2006 & The Government started the Mission Science Plan \\
\hline
\end{tabular}

Table3. Thematic Networks on Biotechnology, 2014

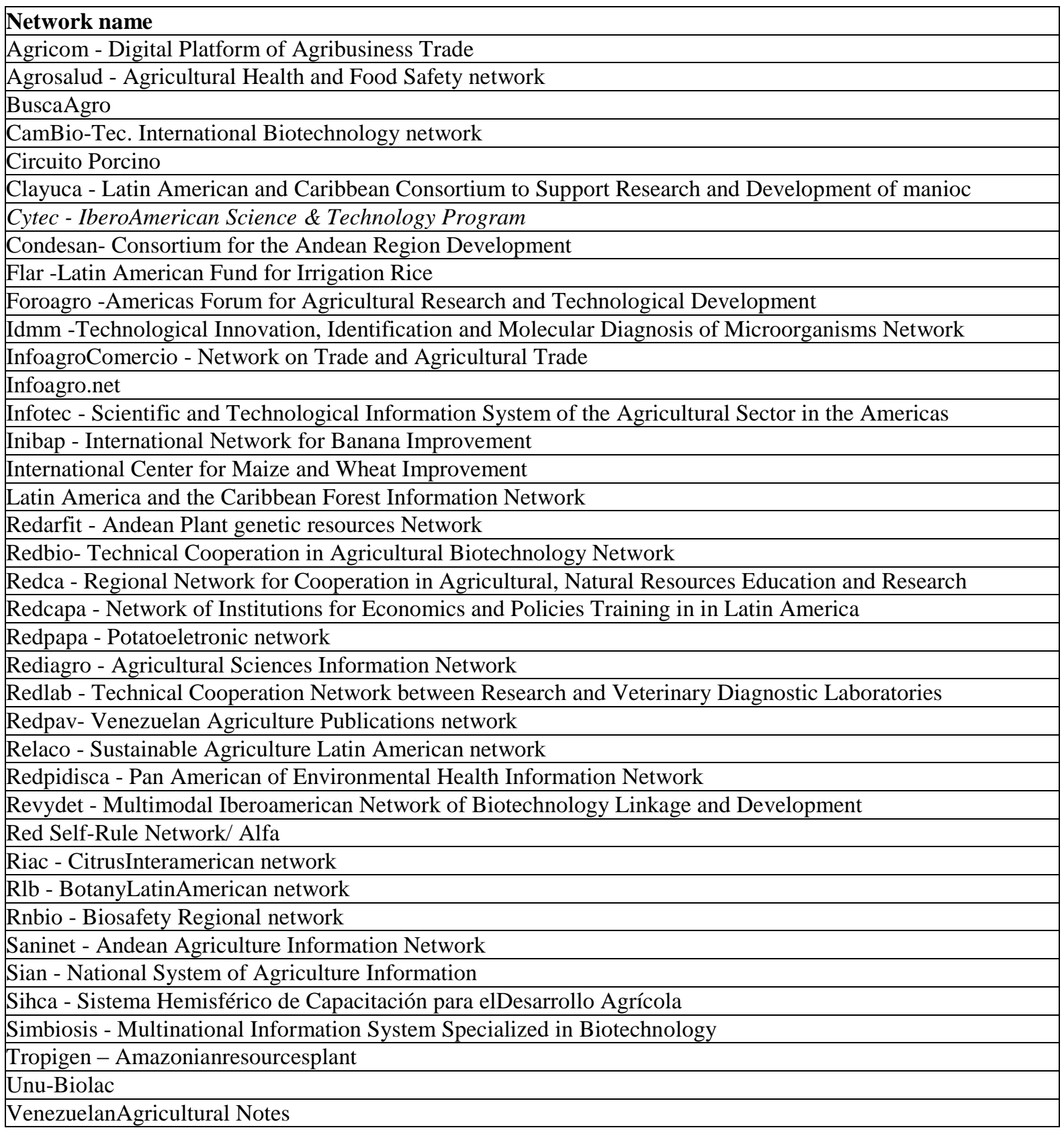

\section{Conclusion}

Biotechnology has a strong dependence on basic research, its success in any country is strongly linked to government policies relating to science and its technological diffusion. In Venezuela, this scenario is no different, since Biotechnology was primarily developed by the government policies and 
programs carried out over the last 27 years, but more focused on basic knowledge than applied knowledge. It should be noted that the financing and incentive policies carried out by the Governments were discontinued during the observed period of 15 years and, according to the interviewees, were insufficient to achieve the desired development. Therefore, this aspect was considered as an important obstacle to the development of Biotechnology in the country and should be better managed by government agencies such as MppCT. The Organic Law on Science, Technology and Innovation (2001) was expected to change this scenario in the coming years, as has already been observed in the general scenario of private investment for S,T\&I, since public and private companies, national or foreign, were invited to participate more effectively in the investments of S,T\&I activities in the country.

An observed positive aspect is the scientific tradition of the country in the areas covered by the Biotechnology. The Venezuela's organizations operate in different areas of Biotechnology, however, are concentrated mainly in the areas: Agriculture and Life Sciences and, they are primarily governmental public character, so few industries were found developing research and/or technology in the area, as is the example of the Polar food and beverage company.

Regarding the training of human resources, it was found that there is a small number of professionals working in the sector, however, with qualified profile from undergraduate to MSc. and $\mathrm{PhD}$ degrees, representing the latter two almost the same percentage. Because this number is representatively small, about $11 \%$ of the total, it is necessary to stimulate the formation of human resource in order to increase the number of researchers dedicated to this area. It was also observed that these researchers are oriented to work in universities or public $R \& D$ institutions and few will work in companies, since there is little exchange and joint activities between these actors and there are few companies in the industry.

Regarding the development of Biotechnology in Venezuela, some aspects should be considered: the development of more targeted government policies in this area with specific programs dedicated to it; the training of human resources in order to increase the number of researchers dedicated to the area of practice as well as to create more programs to encourage the multinational exchange to exchange experiences. The Government recently sought to encourage this path through the participation of Venezuelan institutions in various international networks such as REDBIO/FAO and the various international cooperation agreements signed with Latin American, Asian and Arab countries.

It can be concluded that there is still a long way to be decided by politicians and scientific managers in relation to the formation and consolidation of a Sectorial System of S,T\&I for Biotechnology in Venezuela in order to achieve the desired economic and social development. To do this, some relevant aspects should be considered, such as: - the creation of programs focused on the specific problems of the country, looking for the development of internal solutions using Venezuelan skills and national companies; - create new funding arrangements which are suitable for the development of industry knowledge (expertise), as well as basic research in order to provide continued funding over time, lasting in addition to being able to attract new investments (Venture capital) to start-ups. develop a specific legislative apparatus that covers all the themes of the areas involved.

\section{REFERENCES}

[1] Santana, M.F.E.; Martínez, R.G.; Pereira Jr.,N.; Antunes, A.M.S. (2012). Knowledge Management and Analysis of Scientific Biotechnology Trends in Venezuela. J. Technol. Manag Innov., 7(1), pp 44-58.

[2] Valle, M.G. (2005). O Sistema Nacional de Inovação em Biotecnologia no Brasil: Possíveis Cenários. Tese de Doutorado. Instituto Geociências. Unicamp, pp 1-264.

[3] Freeman, C. (1987). Technology Policy and Economic Perfomance. Lessons from Japan. Pinter Publisher, London and NY, pp 155.

[4] Etzkowitz, H.; Leydesdorff, L, (2000). The Dynamic of Innovation: from National Systems and "Mode 2" to a Triple Helix of University-Industry-Government Relations. Research Policy, 29, pp 109-123.

[5] Torres, O.D.; Velho, L. (2009). Capacidades Científicas y Tecnológicas de Colombia para adelantar Prácticas de Bioprospección. Revista CTS, 4 (12). pp 55 - 68. 
[6] Van Eck, NJ, Waltman, L, (2010). Software survey: VOSviewer, a computer program for bibliometric mapping”. Scientometrics. 2010. 84 (2), 523-538. DOI: 10.1007/s11192-009-01463.

[7] La Rosa, I.; (2006). Investigación y Desarrollo Tecnológico em Venezuela. Informe Foresight SCOPPE 2015. Scenarios for Research \& Technology Development Cooperation with Europe, $1-31$.

[8] Aldao, R.R. La Política Científica y Tecnológica de Venezuela (1999-2008) (2008). Bitácora-e Revista Electrónica Latinoamericana de Estudios Sociales, Históricos y Culturales de la Cienciala Tecnología, 2008, No. 2

[9] Melendez, L; Córdova, M.Y; Marcano, L; Romero, G. (2007). Estudio Prospectivo para el Fortalecimeinto del Sector Biotecnológico como Apoyo a la Seguridad Alimentaria del País. MCTI. pp 153.

[10] National Postgraduate Council (2009) [Available from: http://www.ccnpg.gob.ve/estadisticas] [Accessed: 2016-12-15]

[11] Morales (2006). Biotechnology research in Venezuela: Five case studies. Electron. J. Biotechnol. V.9, n.5 Valparaíso, oct. 2006, pp 461-466.

[12] OEI (2010). Observatorio Iberoamericano de Ciencia, Tecnología y Sociedad del Centro de Altos Estudios Universitarios. La biotecnología en Iberoamérica Situación actual y tendências. [Available from: http://www.oei.es/historico/divulgacioncientifica/noticias_080.htm] [Accessed: 2016-12-10]

[13] Unesco (2010). estudios y documentos de política científica de alc. Sistemas nacionais de ciência, tecnologia y inovación en America Latina y el Caribe. Oficina regional de ciência para America Latina y el Caribe. $1^{\text {a }}$ Edición. 2010. Pp.325. ISBN: 978-92-9089-141-3

[14] Ministério de Ciencia y Tecnología (2006). Plan Nacional de Ciencia, Tecnología e Innovación. Construyendo um Futuro Sustentable. Venezuela 2005 -2030, pp 1-152.

[15] CYTED (2016). Programa Iberoamericano de Ciencia y Tecnologia para el Desarrollo. Redes temáticas. 2016 [Available from: http://www.cyted.org/en/node/4801] [Accessed: 2016-12-05]

[16] Aguillera, M. (2006). Situación actual de la Biotecnología y Bioseguridad en la República Bolivariana de Venezuela. Una Visión Global. República Bolivariana de Venezuela, pp 107. 